Ethiopian Journal of Environmental Studies \& Management 8(5): 606 - 615, 2015.

ISSN:1998-0507

doi: http://dx.doi.org/10.4314/ejesm.v8i5.13

Submitted: April 23, 2015

Accepted: July 27, 2015

\title{
A REVIEW OF CURRENT TECHNIQUES OF IN SITU PHYSICO-CHEMICAL AND BIOLOGICAL REMEDIATION OF HEAVY METALS POLLUTED SOIL
}

\author{
*DADA, E.0., ${ }^{1}$ NJOKU, K.L.,1 ${ }^{1}$ OSUNTOKI, A.A. ${ }^{2}$ AND AKINOLA, M.0.1 \\ ${ }^{1}$ Department of Cell Biology and Genetics, University of Lagos, Akoka, Yaba, Lagos. Nigeria \\ ${ }^{2}$ Department of Biochemistry, University of Lagos, Akoka, Yaba, Lagos, Nigeria
}

\begin{abstract}
Soil plays crucial and strategic life-supporting roles as man and many other living organisms depend directly or indirectly on if for food and shelter. In spite of this fact, the soil is constantly subjected to various forms of abuse, including heavy metals pollution. The ecological destructive effect, high cost, and intensive labour requirement associated with ex situ physico-chemical remediation methods make the search for in situ remediation techniques inevitable. This paper gives an update on the remediation techniques that can be carried out in situ. Included in the review are more recent biological remediation methods, like vermiremediation, which are especially eco-friendly, cost effective, and sustainable.
\end{abstract}

Key Words: Bioremediation, bioaccumulation, heavy metals, soil

\section{Introduction}

The term, heavy metals, has been variously defined by different authors using different physicochemical parameters such as density (specific gravity), atomic number, and chemical properties. Though the term has not been defined by any authoritative body such as the International Union of Pure and Applied Chemistry (IUPAC), the term 'Heavy Metals' usually refers to a group of metals and semi-metals (metalloids) that have relatively high density $\left(>5 \mathrm{~g} / \mathrm{cm}^{3}\right)$ and are associated with contamination and ecotoxicity (Duffus, 2001). Lenntech (2004) defined a heavy metal as any metallic chemical element that has a relatively high density and is toxic or poisonous at low concentrations.

\section{Occurrence of heavy metals}

Heavy metals occur in the environment primarily as a component product of weathering and mineralization of soil parent rock materials (pedogenesis) (McLean and Bledsoe, 1992). In rocks, heavy metals exist as their ores in different chemical forms, from which they are recovered as minerals (McLean and Bledsoe, 1992). Heavy metal ores can be sulphides or oxides. Heavy metal sulphides include iron, arsenic, lead, lead-zinc, cobalt, gold-silver, nickel sulphides; while metal oxides include aluminium, manganese, gold, selenium, and antimony oxides. Some metals like iron, copper and cobalt exist both as sulphides and oxides (Duruibe et al., 2007). Input as a result of human (anthropogenic) activities is another source of heavy metals in the environment. Heavy metals are often classified as essential and non-essential. Essential metals (micronutrients) are required in biochemical functions of plants and animals; they include cobalt (Co), copper $(\mathrm{Cu})$, manganese $(\mathrm{Mn})$ and zinc $(\mathrm{Zn})$. Non- 
essential metals have no known functions or benefits in the physiology of animals; they include cadmium $(\mathrm{Cd})$, lead $(\mathrm{Pb})$, mercury $(\mathrm{Hg}$ ), and arsenic (As) (Naidu et al., 2001). However, some non-essential metals have stimulating or inducing effects in plants when applied at low concentrations. For instance, $\mathrm{Cd}$ produces stimulating effects in barley seedlings (Appenroth, 2010).

\section{Heavy metal contamination and pollution} of soil

The terms 'contamination' and 'pollution' are often erroneously used interchangeably in many literature. But in the strict sense, these terms, though related, have different meanings. Contamination is simply the presence of a substance that is potentially harmful above a certain concentration or volume, while pollution is contamination that results, or can result, in adverse biological effects to resident communities. All pollutants are contaminants, but not all contaminants are pollutants (Chapman, 2007). For a bioremediation related topic, the use of the word 'contamination' will be more appropriate since bioremediation is used, most times, where contaminant level is between low to moderate (Schaefer and Juliane, 2007).

Heavy metals are natural constituents of the earth's crust. As a result, all soils naturally contain trace levels of metals. The presence of metals in soils is, therefore, not indicative of pollution. Irrespective of the source of heavy metals in the soil, excessive levels of many of them can cause a destruction of ecological balance resulting in soil quality degradation, crop yield reduction, and poor quality of agricultural products. Moreover, these metals can contaminate the food chain, posing a significant health hazard to man and animals.

\section{Bioavailabilty of heavy metals}

Bioavailability refers to the percentage of a contaminant or chemical that is available for uptake by an organism in its immediate surrounding at a given time. Usually, heavy metals in soil solution have high bioavailabilty and as a result, are often used to approximate the bioavailable metal fraction. Generally, the free ion species of metals in solution are responsible for the acute toxicity of the metals to organisms (McLean and Bledsoe, 1992). Factors which can determine bioavailability of metals include the source of the metals, the oxidation states of the metals, the length of time the metals have been present in the soil, soil $\mathrm{pH}$, redox potential, surface area, cation exchange capacity (CEC), organic matter content, clay content, iron and manganese oxide content, and carbonate content of the soil. In addition, factors such as metal type and its concentration, and presence of competing ion and complexing ligands also affect soil heavy metal bioavailability (McLean and Bledsoe, 1992).

\section{Bioaccumulation and toxicity of heavy metals}

According to Appenroth (2010), there is no substance that is always toxic. The effect of any substance is always dependent on the concentration available to cells. Any heavy metal becomes toxic only when its concentration exceeds a certain threshold in the body. Though some metals play positives roles in the metabolism of plants and animals, they could escape out of control mechanism (such as transport, homeostasis, compartmentalization, and binding to designated cell constituents), leading to malfunctioning of cells, and eventually, toxicity (Flora and Mehta, 2008).

Girard (2014) stated that bioaccumulation of a heavy metal in soil 
solution medium depends on the rate $(\mathrm{R})$ at which it is ingested and the mechanism by which it is eliminated. Usually, the rate of elimination is directly proportional to the organism's concentration (C) of the substance.

Rate of ingestion $=\mathrm{R}$

Rate of elimination $=\mathrm{kC}$

As an organism ingests a chemical, the concentration of the chemical in the body of the organism increases. Eventually, a steady state is established. Thus:

Rate of ingestion $=$ Rate of elimination $\mathrm{kC}=\mathrm{R}$

Where:

$\mathrm{C}=\mathrm{mg} / \mathrm{kg}$

$\mathrm{R}=\mathrm{mg} / \mathrm{day}$

The steady-state accumulation $\left(\mathrm{C}_{\mathrm{S}}\right)$ is therefore:

$\mathrm{C}_{\mathrm{S}}=\mathrm{R} / \mathrm{k}$

For convenience, the rate of elimination is described in terms of the half-life $\left(t_{1 / 2}\right)$ of the chemical. First-order kinetics indicates that the relationship between the rate constant $(\mathrm{k})$ and the $\mathrm{t}_{1 / 2}$ is:

$\mathrm{k}=0.69 / \mathrm{t}_{1 / 2}$

Substituting for $\mathrm{k}$ gives

$\mathrm{Cs}=[\mathrm{R}]\left[\mathrm{t}_{1 / 2}\right] / 0.69$

This equation therefore indicates that the longer the half-life of the chemical, the higher its steady-state accumulation will be (Girard, 2014).

\section{Remediation of heavy metal polluted soil}

Remediation of polluted soils, especially those polluted with heavy metals, is a difficult, time-consuming, and financially demanding operation (Schaefer and Juliane, 2007). It is a worse scenario however, to leave heavy metal polluted soils unremediated, in view of the long term consequences to the environment, plants, animals, and man. Heavy metal contaminated or polluted soils can be remediated by physico-chemical and biological techniques. Each of these techniques can be carried out by ex situ and or in situ method. Ex situ remediation method involves excavation of the contaminated top soil to somewhere else for treatment while in situ method involves remediating the contaminated soil on site (Maenpaa et al., 2002; Wuana et al., 2010; Rahimi et al., 2012). Some remediation methods can be carried out by both in situ and ex situ methods. The choice of remediation method depends on the site characteristics, contaminant concentration, type of contaminants or pollutants to be remediated, and the final use of the contaminated soil (Jankaite and Vasarevicius, 2005). Generally, in situ remediation technique is often preferred over ex situ because the former is always cheaper and less destructive to the ecosystem (Khan et al., 2000). Hence, this paper focuses on in situ remediation techniques. In situ remediation can be carried out by physico-chemical or biological method (Bioremediation).

In situ physico-chemical techniques of remediating heavy metals polluted soil

Several physico-chemical remediation methods that can be carried out in situ are available. Those suitable for heavy metal removal or confinement include soil isolation and containment, solidification and stabilization, vitrification, soil flushing, and electrokinetics/electroreclamation (Jankaite and Vasarevicius, 2005; ICS, 2005).

\section{Soil isolation and containment}

This is an in situ, isolation remediation method in which contaminated soils are capped and contained by installing barriers around a metal contaminated soil to prevent the metal contaminant from spreading to water sources close to the site or to avoid the dispersion of the contaminant from the site. The barrier walls (slurry walls), which are usually made of impermeable materials 
(such as steel, cement, bentonite, and grout) are used for capping, vertical and horizontal containment. Capping reduces water filtration, vertical walls minimize movement of contaminated groundwater from the contaminated site or limit the flow of uncontaminated water into the contaminated site, while horizontal barriers are potentially useful in restricting downward movement of metal contaminants. The location of the barrier, its thickness and integrity are all design specifications that may or may not be achieved during the installation procedure. This method is not a direct remediation process, but a measure used to significantly reduce the migration of metals into the groundwater (Mulligan et al, 2001; ICS, 2005; Jankaite and Vasarevicius, 2005).

\section{Solidification and Stabilization}

Solidification and stabilization are twin technologies that use binders and additives to reduce metal contaminants' mobility. In solidification, contaminated soils are mixed with a physical binding agent such as cement, bitumen, asphalt, thermoplastic binders to form a crystalline, glassy, or polymeric mass which have low leaching rates. In stabilization, chemical reactions are induced between the stabilizing agent and metal contaminants. This is to bind the contaminants to substrate or to yield less mobile compounds which contain the metal contaminants. Stabilization does not necessarily yield a solid, but a more chemically stable compound. The resultant compound can thereafter be removed from the contaminated environment if desired (ICS, 2005; Jankaite and Vasarevicius, 2005).

\section{Vitrification}

Vitrification is a solidification / stabilization process requiring thermal energy. The technology uses electricity to heat and melt contaminated soil to a sufficiently high temperature to cause it to melt and form an inert gas when cooled. The process involves the insertion of graphite electrodes into the contaminated soil, at sufficiently close spacing, and energizing with a high electrical resistance heating $\left(>1700^{\circ} \mathrm{C}\right)$ which causes the soil to melt to a molten pool. On cooling, a glassy solid is formed which immobilizes the metals. However, the resultant glassy solid can be removed from the site. Solidification/stabilization and vitrification techniques are suitable for pollution of shallow depths and of a large volume (Mulligan et al, 2001; ICS, 2005; Jankaite and Vasarevicius, 2005).

\section{Soil flushing}

Soil flushing is an in situ remediation method for removing contaminants from the soil by the use of water or appropriate washing solution. Acids, bases, and surfactants are added to water and used as extraction or flushing solutions to recover metals, organic and oil contaminants like phenol (ICS, 2005; Jankaite and Vasarevicius, 2005). The extraction or flushing solutions are injected directly or infiltrated into the soil using surface flooding, sprinklers, surface trenches, horizontal drains, or vertical drains. Contaminants are mobilized by solubilization, formation of emulsions or a chemical reaction with the extraction solution. Contaminants that are dissolved in the flushing solution are leached into the groundwater. The contaminant-bearing water and flushing solution are then collected through strategically placed wells or trenches and brought to the surface for removal, recirculation or onsite treatment and reinjection. Chemical enhanced soil flushing has great potential for a wide range of metals. 


\section{Electrokinetics/electroreclamation}

Electrokinetics remediation (electroreclamation) involves passing a low intensity electric current between ceramic electrodes that are divided into a cathode and an anode array imbedded in the contaminated soil. Ions and small charged particles, in addition to water, are transported between the two electrodes. Anions move towards the positive electrodes while cations move towards the negative electrodes. An electric gradient initiates movement by electro-migration (charged chemicals movement), electroosmosis (movement of fluid), electrophoresis (charged particles movement), and electrolysis (chemical reactions due to an electric field) (Rodsand and Acar, 2000; Mulligan et al., 2001). Buffer solutions are used to maintain the $\mathrm{pH}$ at the electrodes. Contaminant metals arriving at the electrodes can be removed by electroplating or electrodeposition, precipitation or co-precipitation, adsorption, complexing with ion exchange resins, or pumping of water or any other fluid near the electrodes by using ion exchange resistance (ICS, 2005; Jankaite and Vasarevicius, 2005). Metals which occur as soluble ions and bound to soil such as oxides, hydroxides and carbonates are removed by this remediation process. This method can be effective for removing contaminants in clay soils of a low permeability. It is suitable for saturated soils with low groundwater flow rates. Biological remediation (Bioremediation) of heavy metals polluted soil

Bioremediation is one of the nature's ways of purifying contaminated environment. Bioremediation includes all those processes and actions that take place in order to biotransform an environment by the use of living organisms to remove or detoxify contaminants within the environment (Gupta et al., 2003; Rahimi et al., 2012). Although, traditionally, bacteria are the reference organisms in bioremediation (microbial remediation/microremediation), the present day bioremediation technologies are based on processes and potential of almost all life forms. In addition to the traditional bioremediation (microbial remediation/microremediation), other emerging bioremediation techniques include phytoremediation, phycoremediation, mycoremediation, zooremediation, and vermiremediation (Garbisu and Alkorta, 2003; Gifford et al., 2006; Sinha et al., 2009; Rahimi et al., 2012). Out of these, those suitable for remediating heavy metal contaminated soils include microbial remediation, phytoremediation, mycoremediation, and vermiremediation. These bioremediation methods are preferred over other methods because they are cost effective and non- or less destructive to the ecosystem (Khan et al., 2000; Sinha et al., 2009).

\section{Microbial remediation/microremediation}

Microbial remediation is the use of microorganisms or microbial processes to degrade and transform environmental contaminants into harmless or less toxic forms (Garbisu and Alkorta, 2003). The microorganisms may be native to the contaminated area or they may be isolated and brought to the site (Vidali, 2001). The soil microbial community is highly diverse, consisting of bacteria, fungi, and protozoa (Giller et al., 1998). Microbial remediation is especially useful in remediating organic contaminants such as solvents, polyaromatic hydrocarbons (PAHs), polychlorinated biphenyls (PCBs), pesticides (Gupta et al., 2003; Adeniji, 2004). The use of microorganisms to remediate heavy metal contaminated soils is somehow limited (Sinha et al., 2009) for 
the fact that metals do not readily undergo either chemically or biologically induced degradation. This fact notwithstanding, some metal-tolerant bacteria can detoxify metals by valence transformation, extracellular chemical precipitation, or volatilization thereby altering the mobility and bioavailability of metals.

Bacteria use a number of mechanisms to resist and cope with heavy metals. Such mechanisms include binding the metals to proteins, extracellular polymers or the cell wall, compartmentation or sequestration of metals within the cells, forming insoluble metal sulphides, enzymatic reduction, metal efflux pumps, production of metal chelators such as metallothioneins and biosurfacants, and volatilization of metals (Giller et al., 1998; Sinha et al., 2009). Microorganisms commonly used in remediation mechanisms include strains of Staphylococcus, Bacillus, Pseudomonas, Citrobacteia, Klebssilla, and Rhodococcus. Strains of Alcaligenes and Pseudomonas have been used in reducing chromium toxicity. Strains of Escherichia and Pseudomonas have been used in reducing the toxicity and bioavailability of copper. The mechanisms employed in the use of these organisms for bioremediation include (1) bioaugmentation, in which microbes and nutrients are added to contaminated site, and (2) biostimulation in which nutrients and enzymes are added to supplement the intrinsic microbes of the site (Adeniji, 2004).

A major limitation of bioremediation of heavy metal contaminated soils using microorganisms is that though the metals are concentrated or converted to less toxic forms, they are still present in the soil. An exception to this limitation is mercury. Soluble mercuric ion $\left(\mathrm{Hg}^{2+}\right)$ can be reduced to volatile metallic mercury by microorganisms thereby effectively removing it from the soil (Garbisu and Alkorta, 2003).

\section{Phytoremediation}

Phytoremediation is a remediation technique that uses plants to remove contaminants from the environment. The term 'Phytoremediation' was coined in 1991 (Vidali, 2001). It is a cost-effective, simple, environment and ecosystem friendly remediation technique. Many research works have consistently demonstrated that some plant species have the potential to remove, degrade, metabolize, or immobilize a wide range of organic and inorganic contaminants including heavy metals (Vidali, 2001; Garbisu and Alkorta, 2003; Njoku et al., 2009; Sinha et al., 2009; Rahimi et al., 2012). Most of these plants are weeds (Banks et al., 2000), but the use of food crop plants is being advocated due to the possibility of added economic return (Njoku et al., 2009).

The various techniques employed by plants in phytoremediation include phytoextraction (phytoaccumulation), phytovolatilization, phytostabilization, rhizofiltration, phytostimulization. Phytoextraction exploits vascular plants' natural abilities to take up a variety of chemical elements through the root systems, deliver them to the vascular tissues, and thereafter compartmentalize them in different organs. The shoot biomass or whole plant can be harvested and disposed of safely or burnt to recover the contaminant metal (Rahimi et al., 2012). A technique evolving from phytoextraction is called Phytomining, in which plants are used to extract or mine metals of high economic value (Gupta $e t$ al., 2003). Phytostabilization is a technique in which contaminant heavy metals' mobility is reduced, thereby preventing lateral or vertical migration of the toxic 
metals (Jankaite and Vasarevicius, 2005). Phytovolatization is a mechanism by which plants convert a contaminant into volatile form and transpire the detoxified vapour through their shoots. Volatile heavy metals like mercury and selenium can be remediated by this technique (Rahimi et al., 2012).

\section{Mycoremediation}

Mycoremediation is a bioremediation process in which fungi including mushrooms are used to remediate contaminants, including heavy metals. One of the primary roles of fungi, such as mushrooms, in the ecosystem is biodegradation or decomposition which is performed by the mycelium. The mycelium secretes extracellular enzymes and acids that break down lignin and cellulose. Mushrooms possess a very effective mechanism that enables them to readily take up metals from the ecosystem (Turkekul et al., 2004), and as such can be used to evaluate the level of environmental pollution, and remediate metal contaminated soil (Sesli and Tuzen, 1999; Asiriuwa et al., 2013). Asiriuwa et al.(2013) used mycoremediation technique to assess the bioaccumulation potential of heavy metals $(\mathrm{Cd}, \mathrm{Zn}, \mathrm{Cu}, \mathrm{Pb})$ by mushrooms from heavy metal contaminated soils. Results obtained from the study revealed that mushrooms can bioaccumulate heavy metals from metal contaminated soil.

\section{Zooremediation}

Zooremediation is the process of removing pollutants through the activities of animals. Animals used for this purpose include arthropods, fishes, filter feeders in the aquatic systems, and the earthworms in the soil environment (Gupta et al., 2003). Animals are not always considered for bioremediation owing to ethical, human, and ecological safety concerns.
Nonetheless, many invertebrates like oysters, mussels, clams, fish, polychaetes, sponges and earthworms are considered suitable for bioremediation since in many jurisdictions, the term 'animals' refers to 'all live non-human vertebrates' (Gifford et al., 2006).

\section{Vermiremediation}

Vermiremediation is the use of earthworms to clean up contaminants from the soil environment. It has been discovered that earthworms are tolerant to, and can remove, or aid the removal of a wide range of organic and inorganic contaminants such as pesticides, polycyclic aromatic hydrocarbons (PAH), crude oil and heavy metals from the soil (Shahmansouri et al., 2005; Pattnaik and Reddy, 2011; Dada, 2015). While earthworms may remove or aid the removal of organic contaminants through a number of mechanisms such as biodegradation, biotransformation, and physical actions, the main mechanism employed by earthworms in metal removal is bioaccumulation through dermal absorption and intestinal intake. Some earthworm species have been found to have the ability to accumulate and retain high level of heavy metals. Among them are Eisenia fetida, Aporrectoda tuberculata, Lumbricus terrestris, Lumbricus rubellus, Dendrobaena rubida, Dendrobaena veneta, Eiseniella tetraedra, Allobophora chloritica, Libyodrilus violaceus (Sinha et al., 2010; Dada, 2015). Andersen and Laursen(1982), as cited by Pattnaik and Reddy(2011), described three general mechanisms by which earthworms cope with high tissue-metal burdens: (1) they may immobilize the metals in chloragogen, which are fatty cells of the gut wall; (2) they may store the metals in waste nodules (brown bodies); (3) the metals may be excreted through the calciferous glands. Generally, sub-cellular mechanisms or 
processes involved in metal accumulation and detoxification by earthworms include the induction of metallothioneins (metalbinding protein) and subsequent sequestration and storage of the metallothinein-bound metals in structures such as granules (Li et al., 2010).

Hickman and $\operatorname{Reid}(2008)$ highlighted possible approaches for vermiremediation: (1) by direct application of earthworms to contaminated soils; (2) co-application of earthworms to contaminated soils with another organic media such as compost; (3) application of contaminated media to earthworms as part of a feeding regime; (4) indirect use of earthworms through the application of vermidigested material (vermicompost).

\section{Conclusion}

Industrial and technological advancements, as desirable as are, come with lots of challenges, of which environmental pollution is foremost. The traditional physico-chemical remediation methods, which are usually the first line of treatment, also leave the problem of ecological upset behind. This is more so if the remediation is done ex situ. It is therefore imperative to focus research efforts at making the emerging in situ remediation methods more available, affordable, and sustainable. In situ biological remediation methods are especially ecosystem friendly and sustainable. They can be combined with other physico-chemical remediation methods to achieve better results.

\section{References}

Adeniji, A. (2004). Bioremediation of arsenic, chromium, lead, and mercury. A document submitted to US Environmental protection Agency Office of Solid Waste and Emergency
Response Technology Innovation Office, Washington D.C., 43 pp.

Appenroth, K.J. (2010). 'Definition of heavy metals and their role in biological systems'. In: Sherameti, I. and Varma, A. (eds). Soil Heavy Metals (19): 429. Springer-Verlag, Berlin Heidelberg.

Asiriuwa, O.D., Ikhuoria, J.U. and Ilori, E.G. (2013). Myco-remediation of heavy metals from contaminated soil. Bulletin of Environment, Pharmacology and Life Sciences 2(5):16-22.

Banks, M.K., Govindaraju, R.S., Schwab, A.P. and Kulakow, P. (2000). Part 1: Field demonstration. In: Fiorenza, S., Oubre, C.L. and Ward, C.H. (eds), Phytoremediation of Hydrocarboncontaminated Soil. Pp 3-88, Baton Rouge, LA, Lewis Publishers.

Chapman, P.M. (2007). Determining when contamination is pollution - weight of evidence determinations for sediments and effluents. Environment International 33(4): 492-501.

Dada, E.O. (2015). Heavy metal remediation potential of a tropical wetland earthworm species, Libyodrilus violaceus. Ph.D. Thesis, Department of Cell Biology and Genetics, University of Lagos, Lagos, Nigeria, 192 pp.

Duffus, J.H. (2001). Heavy metals - a meaningless term. Chemistry International A publication of IUPAC, Vol. 23, No. 6, 4 pp.

Duruibe, J.O., Ogwuegbu, M.O.C. and Egwurugwu, J. N. (2007). Heavy metal pollution and human biotoxic effects. International Journal of Physical Sciences 2(5): 112-118.

Floral S.J.S., M.M. and Mehta, A. (2008). Heavy metal induced oxidative stress and its possible reversal by chelation therapy. Indian Journal of Medical Research 128: 501-523. 
Garbisu, C. and Alkorta, I. (2003). Basic concepts on heavy metal soil bioremediation. The European Journal of Mineral Processing and Environment Protection 3(1): 58-66.

Gifford, S., Dunstan, R.H., O'Connor, W., Koller, C.E. and MacFarlane, G.R. (2006). Aquatic zooremediation: deploying animals to remediate contaminated aquatic environments. Trends in Biotechnology 25(2): 60-65.

Giller, K.E., Witter, E., McGrath, S.P. (1998). Toxicity of heavy metals to microorganisms and microbial processes in agricultural soils: a review. Soil Biology and Biochemistry 30:1389-1414.

Girard, J.E. (2014). Principles of Environmental Chemistry $3^{\text {rd }}$ edition, Jones and Barlett Learning, USA, 711 pp.

Gupta, A.K., Yunus, M., and Pandey, P.K. (2003). Bioremediation: ecotechnolgoy for the present century. Enviro New, Bulletin of the International Society of Environmental Botanists 9(2).

Hickman, Z.A. and Reid, B.J. (2008). Earthworm assisted bioremediation of organic contaminants. Environment International 34(7): 1072-1081.

International Centre for Science and High Technology (ICS). (2005). Survey of remediation technology. ICS, Trieste, Italy, $157 \mathrm{pp}$.

Jankaite, A. and Vasarevicius, S. (2005). Remediation technologies for soils contaminated with heavy metals. Journal of Environmental Engineering and Landscape Management XII(2): 109a-113a.

Khan, A.G., Kuek, C., Chaudhry, T.M., Khoo, C.S. and Hayes, W.J. (2000). Role of plants, mycorrhizae and phytochelators in heavy metal contaminated land remediation. Chemosphere, 21: 197-207.

Lenntech Water Treatment and Air Purification. (2004). Water Treatment Bulletin of Lenntech, Rotterdamseweg, Netherlands, 3 pp.

Li, L., Zhou, D., Peijnenburg, J.G.M., Wang, P., van Gestel C.A.M., Jin, S. and Wang, Q. (2010). Uptake pathways and toxicity of $\mathrm{Cd}$ and $\mathrm{Zn}$ in earthworm Eisenia fetida. Soil Biology and Biochemistry 42: 1045 1050.

Maenpaa, K.A., Kukkonen, J.V.K., and Lydy, M. J. (2002). Remediation of heavy metal- contaminated soils using phosphorus: Evaluation of bioavailability using an earthworm bioassay. Archives of Environmental Contamination and Toxicology 43: 389-398.

Mclean, J.E. and Bledsoe, B.E. (1992). Ground water issue. United States Environmental Protection Agency: Ground Water Issue EPA/540/592/018, 25 pp.

Mulligan, C.N., Yong, R.N. and Gibbs, B.F. (2001). Remediation technologies for metal-contaminated soils and groundwater: an evaluation. Engineering Geology, 193-207.

Naidu, R., Krishnamurti, G.S.R., Wenzel, W., Megharaj, M. and Bolan, N.S. (2001). 'Heavy metal interactions in soils and implications for soil microbial biodiversity.' In: Prasad, M. N. V. (ed), Metals in the environment Analysis by Bioderversity Marcel Dekker, Inc., New York.

Njoku, K.L., Akinola, M.O. and Oboh, B.O. (2009). Phytoremediation of crude oil contaminated soil: the effect of growth of Glycine max on the physico-chemistry and crude oil 
contents of soil. Nature and Science 12: $22-30$.

Pattnaik, S. and Reddy, M.V. (2011). Heavy metals remediation from urban wastes using three species of earthworm (Eudrilus euginiae, Eisenia fetida and Perionyx excavates). Journal of Environmental Chemistry and Ecotoxicology 3(14): 345-356.

Rahimi, M., Farhardi, R. and Yusef, P.H. (2012). Phytoremediation of Arsenic. International Journal of Agronomy and Plant Production 3(7): 230-233.

Rodsand, T and Acar, Y.B. (2000). Electrokinetic extraction of lead from spiked Norwegian marine clay. Geoenvironmental 2: 1518-1534.

Schaefer, M. and Juliane, F. (2007). The influence of earthworms and organic additives on the biodegradation of oil contaminated soil. Applied Soil Ecology 36(1): 53-62.

Sesli, E. and Tuzen, M. (1999). Levels of trace elements in the fruiting bodies of macrofungi growing in the East Black Sea region of Turkey. Food Chemistry 65:453-460.

Shahmansouri, M.R., Pourmoghadas, H., Parvaresh, A.R. and Alidadi, H.
(2005). Heavy metals bioaccumulation by Iranian and Australian earthworms (Eisenia fetida) in the sewage sludge vermicomposting. Iranian Journal of Environmental Health, Science, Engineering 2(1): 28-32.

Sinha, R.K., Chauhan, K., Valani, D., Chandran, V., Soni, B.K., and Patel, V. (2010). Earthworms: Charles Darwin's 'Unheralded Soldiers of Mankind': Protective and productive for man and environment. Journal of Environmental Protection 1: 251-260.

Turkekul, I., Elmastas, M. and Tuzen, M. (2004). Determination of iron, copper, manganese, zinc, lead and cadmium in mushroom samples from Tokat, Turkey. Food Chemistry, 84:389-392.

Vidali, M. (2001). Bioremediation: An overview. Pure and Applied Chemistry 73(7): 1163-1172.

Wuana, R.A. and Okieimen, F.E. (2011). Heavy metals in contaminated soils: A review of sources, chemistry, risks and best available strategies for remediation. ISRN Ecology ID402647. doi:10:5402/2011/402647, $20 \mathrm{pp}$. 